\title{
The prevalence of Infectious Bronchitis (IB) outbreaks in some chicken farms: II. Molecular characterization of field isolates of IB virus
}

\author{
K. M. Kamel ${ }^{1}$, A. Khafagy ${ }^{2}$, A. A. Bassiouni ${ }^{3}$, M. A. Afify ${ }^{3}$, N. S. Rabie ${ }^{3}$ \\ ${ }^{l}$ Department of Poultry Diseases, National Research Center, Cairo, ${ }^{2}$ Department of Poultry \\ Diseases, Animal Health Research Institute, Dokki, Giza and ${ }^{3}$ Department of Poultry Diseases, \\ Faculty of Veterinary Medicine, Cairo University, Giza, Egypt.
}

\begin{abstract}
Twenty five isolates of IBV were isolated from 36 broiler and layer chicken farms collected from 13 governorates during 2 years started from January 2003. All the examined farms were vaccinated using the commercial live $\mathrm{IB}-\mathrm{H}_{120}$ vaccine in addition to the IB-inactivated vaccine in the layer farm. The viruses were isolated and identified previously by chicken embryo, CEK cell culture inoculation. Isolates subjected to RT-PCR. Four isolates; three broiler farms and one from layer farm were genotyped using S1 partial gene sequencing. Typing of the four isolates using S1 partial gene sequencing, revealed that the isolated IBV strains showed homology to Asia, Europe, USA and Middle East strains.
\end{abstract}

IBV, is a prototype of family Coronaviridae, It contains three major structural proteins: the phosphorylated nucleocapsid $(\mathrm{N})$ protein which is internally located, the membrane (M) glycoprotein and the spike (S) glycoprotein, which is posttranslationally cleaved into $\mathrm{N}$ terminal S1 (92 KD) and C-terminal S2 subunites (84 KD) as described later (Cavanagh and Naqi, 1997). The S1 subunit is hypervariable, whereas the $\mathrm{N}$ protein contains some regions whose predicted amino acid sequences tend to be conserved among IBV strains (Williams et al., 1992).

Serotype evolution in IBV are associated primarily with changes in the sequence of the S1 glycoprotein, which contains regions associated with virus attachment and epitopes that induce production of neutralizing antibodies (Cavanagh and Davis, 1988; Cavanagh et al., 1988). Different serotypes, subtypes, and variants of IBV are thought to be generated by nucleotide point mutations, insertions or deletion (Kusters et al., 1987; Wang et al., 1993, 1994; Jia et al., 1995), which are responsible for the problem of outbreaks of IB disease in previously vaccinated chicken flocks.

The serotype determinants had been identified in a 395-amino acid region of the S1 subunit, which contain four variable regions. Among European IBV strains of the Mass serotype, two hypervariable regions (HVRs), HVR-1 residues (56-69) and HVR-2 (residues 117-131) were identified (Kusters et al., 1987; Cavanagh et al., 1988). Isolates from the United
States had similar HVRs in the S1 subunit between residues (53-148) (Wang et al., 1993). The virus neutralization (VN) antibodies that form the basis for comparison of IBV isolates were induced largely by the N-terminus of the S1 protein (Koch et al., 1990). The 120 residues of the $\mathrm{N}$ protein $\mathrm{C}$-terminal contain cytotoxic $\mathrm{T}$ lymphocytes (CTL) epitopes that may decrease viral load and induce protective immunity by inducing CTL response in the chicken (Seo and Collisson, 1997).

\section{Materials and methods}

Viruses of IB.

Field isolates. They were obtained previously from 36 chicken farms showing symptoms suspected to be IBV infection.

Oligonucleotide primers. Primers for UTR and S1 were designed according to (Adzhar et al., 1996 ; Cavanagh et al., 1999) (Table 1). S1 primers were designed to detect and differentiate three types of IBV: 793/B (also known as 4/91 and CR88), Massachusetts and D274, using the $\mathrm{S} 1$ region of the $\mathrm{S}$ protein gene.

RNA extraction. RNA was extracted from the allantoic fluid from previously isolated field isolates using Qiagen viral RNA extraction kit according to the manufacturer instructions.

Reverse transcriptase polymerase chain reaction ( RT PCR). RT PCR was performed on the RNA of the examined isolates. RT PCR amplicon was detected in 1.0\% agarose (Hispangar), according to (Adzhar et al., 1996). DNA of amplicons were gel purified and used for direct sequencing. 
Table (1): Primers for amplification of UTR and S1 by RT-PCR assay.

\begin{tabular}{llllll}
\hline Primer & \multicolumn{1}{c}{ Sequence (5'-3') } & Gene & Location & Tm & \multicolumn{1}{c}{ Location reference } \\
\hline UTR2+ & AAGGAAGATAGGCATGTAGCTT & 3`UTR & $234-255$ & $56^{\circ} \mathrm{C}$ & Williams et al., (1993) \\
UTR1- & GCTCTAACTCTATACTAGCCTAT & 3`UTR & $509-531$ & & Williams et al., (1993) \\
XCE1+ & CACTGGTAATTTTCAGATGG & S1 & 728 to 749 & $50^{\circ} \mathrm{C}$ & Adzhar et al., (1997) \\
XCE3- & CAGATTGCTTACAACCACC & S1 & 1093 to 1111 & & Adzhar et al., (1997) \\
\hline
\end{tabular}

Detection IBV and sequencing of a piece of the S1 Gene. It was done according to (Gelb et al., 2005) using BigDye ${ }^{\circledR}$ Terminator v1.1 Cycle Sequencing kit (Applied Biosystem catalog No. 4337450).

\section{Results}

RT PCR for detection of IBV 3 UTR gene. Results revealed that $25 \mathrm{IBV}$-field isolates was positive for UTR motif using RT PCR.

Detection of IBV and partial S1 sequencing.

Results revealed that the $\mathrm{S} 1$ gene was yielded at 385 bp (Fig.2 and Table 2).

Sequence analysis. Broiler isolate code (4) was found to be identical (100\% homology) to Chinese isolate; CK/CH/LDL/011 and Singapore isolate Q1. Broiler isolate code (16) showed 98\% homology to Connectcut strain, $97 \%$ to M41 strain., 96\% with Egypt/F/03 and 96\% with the Chinese isolate GX1-98. Broiler isolate code (18)showed 98\% homology to isolates; $720 / 99$ and 885 isolated from Israel. Layer isolate coded (23)showed 98\% homology to the French isolate FR-94047-94 and 96\% to isolate Spain/92/51 (Table 3 and Fig.2-6).

\section{Discussion}

The IBV genome consists of approximately 27 $\mathrm{kb}$ (Boursnell et al., 1987) and codes of three structural proteins: the spike (S) glycoprotein, the membrane (M) glycoprotein, and the nucleocapsid $(\mathrm{N})$ protein (Lai and Cavanagh, 1997; Enjuanes et al., 2000). In addition, a fourth protein (small membrane protein, E) is believed to be associated with the virion envelope in very small amounts; it is essential for virus particle formation (Cavanagh and Naqi, 2003). The virus has a worldwide distribution, and many variants have been isolated (Davelaar et al., 1984; Wang et al., 1994; Liu et al., 2003). The appearance of antigenic variants of IBV cause a major problem in the poultry industry. Natural outbreaks of IBV are controlled through the use of vaccines. In spite of the routine use of vaccines, IBV outbreaks continue in vaccinated fowls (Gelb, 1989; Wang and Tsai, 1996; Liu et al., 2003). The S protein comprises two or three copies of each of two glycopeptides, S1 and S2 (approximately 520 and 625 amino acids; respectively). Hemagglutination-inhibiting (HI) and most of the neutralizing (VN) antibodies are induced by S1 (Cavanagh et al., 1988; Koch et al., 1990; Jackwood et al., 1992; Ignjatovic et al., 1997).As a result of molecular studies, it was now known that it was the S1 part of the IBV that is responsible for determining its serotype (Cook et al., 1999). Furthermore, a new IBV serotype could arise as a result of only a very few changes in the amino acid composition of the S1 part of the spike protein (Cavanagh et al., 1992), with the majority of the virus genome remaining unchanged. The greatest divergence in the amino acid sequence was concentrated between the residues 53 and 148 of the S1 (Niesters et al., 1986; Wang et al., 1994). Two hypervariable regions (HVR) within the $\mathrm{S} 1$ at positions 56-69 and 117-133 from the beginning of the S1 were also identified (Niesters et al., 1986). The HVR is an essential determinant of coronavirus serotype specificity (Cavanagh and Naqi, 2003). Strain classification or, more appropriatey, serotype or genotype classification of IBV is based on feature of the S protein. The many ways that are used to differentiate isolates of IBV have been thoroughly compared by De Wit, (2000). Traditionally, IBV serotypes have been defined by $\mathrm{VN}$ tests, $\mathrm{VN}$ antibody being iduced by the S1 subunit of the S protein. VN tests are time-consuming, especially because an increasing number of standard sera, corresponding to different serotypes, are included in analysis, and in some cases uncertain classification of serotypes of field isolates results from one-way neutralization did not induce a clear cut classification (Song et al., 1998). Non serological differentiation methods such as polyacrylamide gel electrophoresis (Cowen and Hitchner, 1975), nucleic acid hybridization (Cavanagh, 1989), and oligonucleotide fingerprinting (Kusters et al., 1987) were not hampered by the appearance of new IBV isolates and resulted in an objective typing system. These methods were, however, complex and laborintensive and required large amounts of highly purified virus particles.

RT-PCR has been described previously using IBV RNAs extracted from allantoic fluid, and this technique has been shown to be very 

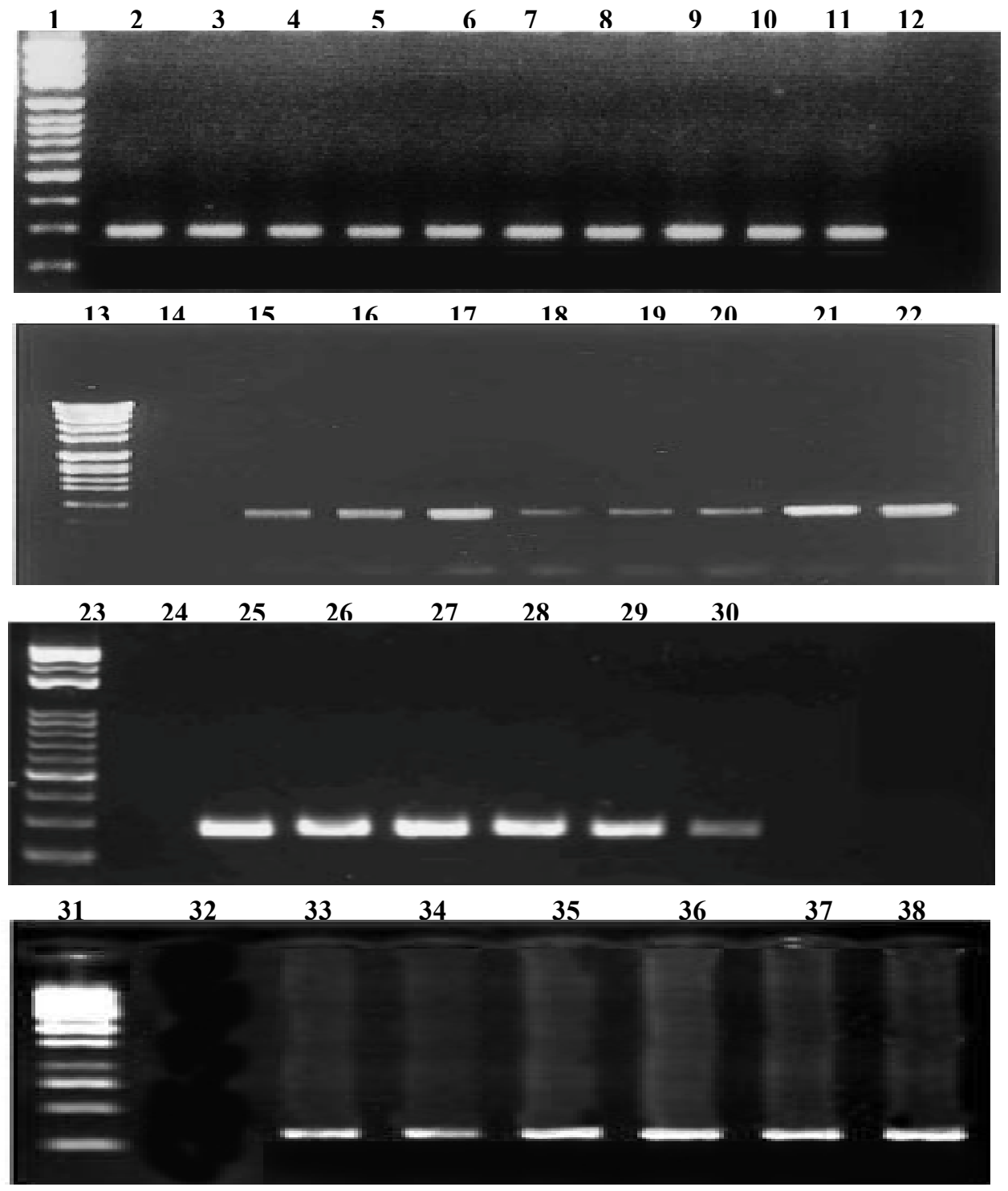

Fig. (1): RT-PCR for 25 IBV-tested AAF of egg embryos. Lanes 1, 13, 23, 31 marker. Lanes 12, 14, 24, 32 Negative Control. Lanes 11, 22, 30, 37, 38 positive control. Lanes 2, 3, 4, 5, 6, 7, 8, 9, 10, 15, 16, 17, 18, 19, $20,21,25,26,27,28,29,33,34,35$ and 36 field IBV tested samples with 298 bp-PCR-products.

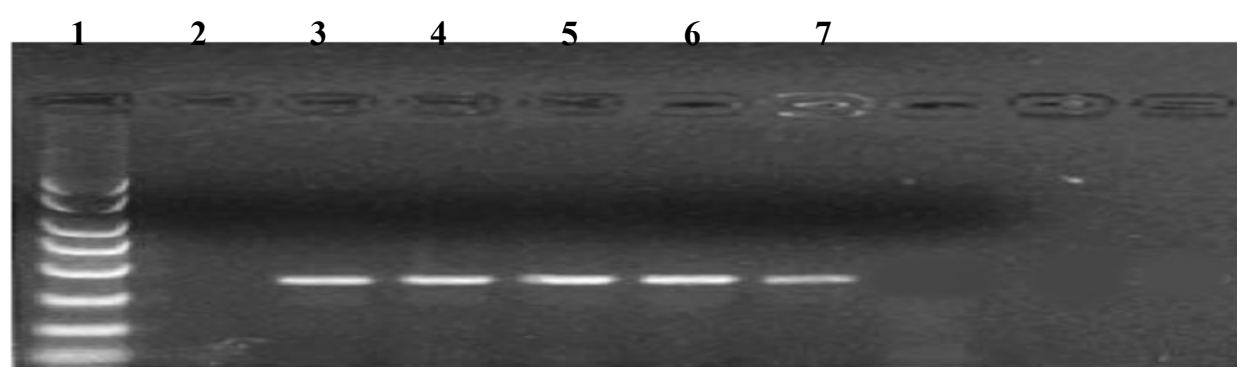

Fig. (2): Sequencing of a part of S1 gene. Lane 1 marker. Lane 2 negative control. Lanes 3, 4, 5, 6 isolates code 4, 16, 18 and 23 gave positive results at 385 bp PCR product. And Lane 7 positive control. 
Table (2): Results of 25 IBV antigen assays.

\begin{tabular}{|c|c|c|c|c|c|c|}
\hline \multirow[t]{2}{*}{ Isolate Code No. } & \multicolumn{3}{|c|}{ IBV-sample reference } & \multirow{2}{*}{$\begin{array}{c}\text { AGPT- } \\
\text { CAM }\end{array}$} & \multirow{2}{*}{$\begin{array}{c}\text { RT-PCR } \\
\text { IBV }\end{array}$} & \multirow{2}{*}{$\begin{array}{c}\text { RT-PCR } \\
\text { IBV Typing }\end{array}$} \\
\hline & $\begin{array}{c}\text { Chicken } \\
\text { Type }\end{array}$ & Age & $\begin{array}{l}\text { Vaccination } \\
\text { against IB }\end{array}$ & & & \\
\hline 1 & Layer & $16 . \mathrm{w}$ & Yes $(\mathrm{L})$ & post & post & neg. \\
\hline 2 & Broiler & $32 . d$ & Yes (L) & post & post & neg. \\
\hline 3 & Layer & $16 . \mathrm{w}$ & Yes (L) & post & post & neg. \\
\hline 4 & Broiler & 39.d & Yes (L) & post & post & post. \\
\hline 5 & Broiler & 36.d & No & post & post & neg. \\
\hline 6 & Broiler & 41.d & Yes $(\mathrm{L})$ & post & post & neg. \\
\hline 7 & Breeder & 33.w & Yes $(\mathrm{L}+\mathrm{I})$ & post & post & neg. \\
\hline 8 & Broiler & $34 . d$ & No & post & post & neg. \\
\hline 9 & Broiler & $34 . d$ & No & post & post & neg. \\
\hline 10 & Broiler & $34 . d$ & No & post & post & neg. \\
\hline 11 & Broiler & $34 . d$ & No & post & post & neg. \\
\hline 12 & Layer & 18.w & Yes $(\mathrm{L}+\mathrm{I})$ & post & post & neg. \\
\hline 13 & Broiler & $25 . d$ & No & post & post & neg. \\
\hline 14 & Broiler & $25 . d$ & No & post & post & neg. \\
\hline 15 & Broiler & $40 . d$ & No & post & post & neg. \\
\hline 16 & Broiler & $24 . d$ & Yes (L) & post & post & post. \\
\hline 17 & Breeder & 29.w & Yes $(\mathrm{L}+\mathrm{I})$ & post & post & neg. \\
\hline 18 & Broiler & 32.d & Yes (L) & post & post & post. \\
\hline 19 & Broiler & $45 . d$ & No & post & post & neg. \\
\hline 20 & Breeder & $69 . \mathrm{d}$ & Yes (L) & post & post & neg. \\
\hline 21 & Broiler & $39 . d$ & Yes (L) & post & post & neg. \\
\hline 22 & Broiler & $39 . d$ & Yes (L) & post & post & neg. \\
\hline 23 & Layer & 54.w & Yes $(\mathrm{L}+\mathrm{I})$ & post & post & post. \\
\hline 24 & Layer & 41.w & Yes $(\mathrm{L}+\mathrm{I})$ & post & post & neg. \\
\hline 25 & Breeder & 34.w & Yes $(\mathrm{L}+\mathrm{I})$ & post & post & neg. \\
\hline
\end{tabular}

Remark: PCR-IBV typing is done by sequencing a part of the $\mathrm{S} 1$ gene.

Table (3): Results of genotyping (matching of a part of S1 gene) of four IBV field isolates.

\begin{tabular}{|c|c|c|c|c|c|c|c|}
\hline \multirow{2}{*}{$\begin{array}{c}\text { IB } \\
\text { isolate } \\
\text { code }\end{array}$} & \multirow{2}{*}{$\begin{array}{l}\text { Sample } \\
\text { reference }\end{array}$} & \multirow{2}{*}{$\begin{array}{l}\text { Vaccination } \\
\text { against IB }\end{array}$} & \multirow{2}{*}{\multicolumn{2}{|c|}{$\begin{array}{l}\text { Match with data } \\
\text { base programme } \\
\text { (Check test file) }\end{array}$}} & \multicolumn{3}{|c|}{ Match with NCBI } \\
\hline & & & & & & Description & Accession No. \\
\hline \multirow[t]{2}{*}{4} & Broiler, 39d & Yes (L) & & match with known & a) & $\begin{array}{l}\text { Match for } 100 \% \text { with isolate } \\
\mathrm{CK} / \mathrm{CH} / \mathrm{LDL} / 011 \text { isolated in } \\
\text { China }\end{array}$ & DQ167130 \\
\hline & & & & & b) & $\begin{array}{l}\text { Match for } 100 \% \text { with isolate } \\
\text { Q1 isolated in Singapore. }\end{array}$ & AF286302 \\
\hline \multirow{2}{*}{16} & Broiler, 24d & Yes (L) & & $\begin{array}{l}\text { Match for } 98 \% \text { with } \\
\text { Connecticut strain. }\end{array}$ & a) & $\begin{array}{l}\text { Match for } 96 \% \text { with isolate } \\
\text { Egypt } / \mathrm{F} / 03 \text {. }\end{array}$ & DQ487085 \\
\hline & & & & $\begin{array}{l}\text { Match for } 97 \% \text { with } \\
\text { M41 strain. }\end{array}$ & b) & $\begin{array}{l}\text { Match for } 96 \% \text { with isolate } \\
\text { GX1-98 isolated in China. }\end{array}$ & A319302 \\
\hline \multirow{2}{*}{18} & Broiler, 32d & Yes (L) & & match with known & a) & $\begin{array}{l}\text { Match for } 98 \% \text { with isolate } \\
720 / 99 \text { isolated in Israel. }\end{array}$ & AY091552 \\
\hline & & & & & b) & $\begin{array}{l}\text { Match for } 98 \% \text { with isolate } \\
885 \text { isolated in Israel. }\end{array}$ & AY279533 \\
\hline \multirow{2}{*}{23} & Layer, 54w & Yes $(\mathrm{L}+\mathrm{I})$ & a) & $\begin{array}{l}\text { Match for } 93 \% \\
\text { with } 4 / 91 \text {. }\end{array}$ & a) & $\begin{array}{l}\text { Match for } 98 \% \text { with isolate } \\
\text { FR-94047-94 isolated in } \\
\text { France. }\end{array}$ & AJ618987 \\
\hline & & & & & b) & $\begin{array}{l}\text { Match for } 96 \% \text { with isolate } \\
\text { Spain/92/51 isolated in } \\
\text { Spain. }\end{array}$ & DQ064801 \\
\hline
\end{tabular}

$\mathrm{d}=$ day, $\mathrm{W}=$ week, $\mathrm{L}=$ Live vaccine, $\mathrm{I}=$ inactivated vaccine.

NCBI = National Center for Biotechnology Information (www.ncbi.nlm.nih.gov). 
GAAAGGTTTATTGTTTATAGAGAAAGTAGTGTTAACACTACCTTAGTGTT

AACTAATTTTACTTTCTCAAATGTTAGTAACGCCCCTCCTAATACAGGTG

GTGTTCATAGTATTGTTTTACATCAAACACAAACAGCTCAGAGTGGTTAT

TATAATTTTAATTTCTCCTTTCTGAGTAGTTTCCGTTATGTAGAATCAGA

TTTTATGTATGGGTCATACCACCCAAAATGTTCATTTAGACTAGAAACTA

TTAATAATGGTTTGTGGTTTAATTCACTTTC

Fig. (3): IBV isolate (4) sequencing of 385 bp product of S1 gene. 100\% homolgy to isolate $\mathrm{CK} / \mathrm{CH} / \mathrm{LDL} / 011$ isolated from China and Q1 strain from Singapore.

\section{CAGAAGTTTATTGTCTATCGTGAAAATAGTATTAATACTACTCTTAAGTT \\ ACACAATTTCACTTTTCATAATGAGACTGGCGCCAACCCTAATCTTAGTG \\ GTGTTCAGAATATTCAAACTTACCAAACACAAACAGCTCAGAGTGGTTAT \\ TATAATTTTAATTTTTCCTTTCTGAGTGGTTTTGTTTATAAGGAGTCTAA \\ TTTTATGTATGGATCTTATCACCCAAGTTGTAATTTTAGACCAGAAACTA TTAATAATGGCTTGTGGTTTAATTCACTTTC}

Fig. (4): IBV isolate (16) sequencing of 385 bp product of S1 gene. 98\% homolgy to Connecticut strain. $97 \%$ homolgy to M41 strain. 96\% homolgy to isolate Egypt/F/03. 96\% homolgy to isolate GX198 isolated in China.

\section{GAAAAGTTTGTTGTGTATCGTGAAAATAGTTTTAATACTACTCAGGTTTT AAATAATTTCACGTTTTATAATGAAAGTAATGCCCCTCCTAATGTTGGTG GTGTTAATACTATTAATCTTTATCAAACACATACAGCTCAGAGTGGTTAT TATAATTATAATTTATCATTCCTGAGTGGTTTTGTGTATAAAGCTTCTGA TTTTATGTATGGATCTTATCACCCAAAGTGTGATTTTAGACCAGANACTA TTAATAATGGTTTGTGGTTTAATTCTCTATN}

Fig. (5): IBV-isolate (18) sequencing of 385 bp product of $\mathbf{S 1}$ gene. 98\% homolgy to isolate $720 / 99$ isolated in Israel. 98\% homolgy to isolate 885 isolated in Israel.

\section{GATAGGTTTATTGTATATCGAGAAAGTAGTATTAACACTACTTTAGAGTT AACTAATTTTACTTTTACTAATGTAAGTAATGCTGCTCCTAACTCAGGTG GCATTCAGACCTTTCAATTATATCAAACACACACCGCTCAGGATGGTTAT TATAATTTTAATTTATCATTTCTGAGTGGGTTTGTGTATAAACCATCTGA TTTTATGTATGGGTCTTACCACCCAAAGTGTAATTTTAGACCAGAGAATA TTAATAATGACTTATGGTTTAATTCATTATC}

Fig. (6): IBV isolate (23) sequencing of $\mathbf{3 8 5}$ bp product of $\mathbf{S 1}$ gene. 93\% homolgy to 4/91. 98\% homolgy to isolate FR-94047-94 isolated in France. 96\% homolgy to Spain/92/51 isolated in Spain.

efficient for the detection of IBV and for the identification of IBV types (Adzhar et al., 1996; Jackwood et al., 1997; Keeler et al., 1998; Handberg, et al., 1999; Meulemans et al., 2001). Laboratories are using Reverse transcriptase polymerase chain reaction (RT-PCR), usually the $\mathrm{S} 1$ part of the $\mathrm{S}$ protein gene, followed by restriction endonuclease analysis or sequencing. Such nucleic acid approaches then define IBV isolates by genotype rather than by serotype.

In our study; in order to use a general method for the detection of IBV strains by a common RT-PCR, we used oligonucleotide pairs based on 3 ' untranslated (UTR) sequence. The 3 ' untranslated (UTR) sequence, unlike the remainder of the IBV genome apart from the 5 leader, is present on all IBV RNAs. This sequence is the most abundant IBV sequence in RNA extracted from infected allantoic fluid. Therefore, one would expect to obtain maximum sensitivity in the RT-PCR when using oligonucleotide pairs based on $3^{\prime}$ (UTR) sequence (Adzhar et al., 1996). We extended the sensitivity of the PCR, by RNA purification prior to the RT-PCR reaction to remove nonspecific inhibitors. The oligonucleotide pair was applied to RNA extracted from allantoic fluid harvested from SPF embryos at the level of 
fifth embryonic passage inoculated with 25 IBV field isolates (found positive in AGP test). By use of this oligonucleotide pair, IBV was detected in all these samples where 298 bp product was detected, each containing one of the 25 IBV strains. This result accords with Adzhar et al., (1996); Jackwood et al., (1997); Keeler et al., (1998); Handberg et al., (1999); Meulemans et al., (2001), and confirm the previous detection of IBV by the AGP-test performed on CAM of inoculated eggs. This result indicated that the oligonucleotide pair is universally applicable on IBV strains and therefore provided a useful tool for detection and identification of IBV isolates (Handberg et al., 1999). This findings confirm the prevalence of IBV in chicken farms since the initial report in Egypt (Ahmed, 1954), followed by several publications concerning the isolation of IBV (Eissa et al., 1963; Ahmed, 1964; Amin and Moustageer, 1977; Sheble et al., 1986; Bastami et al., 1987; Mousa et al., 1988; ElKady, 1989; Mahmoud, 1993; Ahmed, 2002; Abdel Moneim et al., 2002; Madbouly et al., 2002; Sultan et al., 2004; Lebdah et al., 2004; Sediek, 2005).

Antibody based tests for identifiying IBV isolates included virus neutralisation (VN) (Cowen and Hitchner, 1975), hemagglutination inhibition (HI) (Alexander and Chettle, 1977), and the use of S1 specific monoclonal antibodies (Karaca et al.,1992). More recently, tests directed at reverse transcripition - polymerase chain reaction (RT-PCR) amplification of S1 have become more commonly used because their short turn - around time and high degree of specificty (Kingham et al., 2000).

Direct automated cycle sequencing (DACS) stratiges had broad applications in research and diagnostics. The development of DACS procedures were used to diagnosis and study the epidemiology and evolution of viral diseases significant, particular in case of viruses that exhibit antigenic variability (Kingham et al., 2000). The application of S1 -sequence analysis for epizootiological studies of IBV has been proposed. DACS provided sequence information in several days and was applicable to large number of IBV isolates (Kingham et al., 2000).

The most frequently published IBV sequences in Gene Bank are localized at the S1 gene, which is a part of the IBV genome with high variability. Therefore, it provided obvious possibilities for the construction of strainspecific oligonucleotides. Our investigation was designed to identify incidence of three serotypes of IBV (determined according to recent published data in Egypt), we used oligonucleotide primer designed by Adzhar et al.,(1997) which was capable to detect and differentiate three serotypes of IBV (Massachusetts, D274 and 4/91). Massachusettes strain was selected to detect vaccine virus and to cease investigation of a field samples if such virus was shown to be present, D274 was selected as it was reported as dominant variant strain in Egypt in 1980-1991 (Bastami et al., 1987, El Kady, 1989, Madbouly et al., 2002), and 4/91 was selected based on the report of Sultan, (2004) who isolated 6 IBV isolates from white commercial egg laying chickens flocks aged 12-28w, one of them was identified as 4/91 related serotype. When applied this specific primer to infectious allantoic fluid, the oligonucleotide pairs identified the IBV variant strains for four IBV isolates for which they were designed where $385 \mathrm{bp}$ product was detected and none of the others (although, other types might have been present but not detected). Therefore it was believed that these oligonucleotide were type specific and may be used for epidemiological surveillance rather than for primary diagnosis of IBV (Handberg et al., 1999).

Results of S1 sequence analysis of isolate code (4) showed high nucleotide similarities to isolate $\mathrm{CK} / \mathrm{CH} / \mathrm{LDL} / 011$ isolated in China (100\% nucleotide identities), and Q1 isolate isolated in Singapore $(100 \%$ nucleotide identities).

S1 sequence analysis of isolate code (16) revealed its close relatedness to Massachusettes serotype. It showed high nucleotide similarities to M41 (97\% nucleotide identities), Connecticut (98\% nucleotide identities), Beaudette (97\% nucleotide identities), Egypt/F/03 (96\% nucleotide identities), and GX1-98 (96\% nucleotide identities). These findings agreed with that reported by Abdel-Moneim et al., (2006).

S1 sequence analysis of isolate code (18) showed the isolate was matched with isolate $720 / 99$ isolated in Israel $(98 \%$ nucleotide identities), and with isolate 885 isolated in Israel (98\% nucleotide identities). This finding in agreement with that reported by Abdel-Moneim et al., (2002).

S1 sequence analysis of isolate code (23) showed that isolate was matched with isolate FR/94049-94 isolated in France (98\% nucleotide identities), isolate Spain/92/S1 isolated in Spain (96\% nucleotide identities), and with strain 4/91 
(93\% nucleotide identities). This finding accord with the finding reported by Sultan, (2004).

The majority of the variant were isolated from north of country (isolate code 4, 16, 18 and 23 were isolated from Kalubia, Dakahlia, Dakahlia and Giza; respectively). Therefore, it is not possible to draw any conclusion regarding the geograhic distribution of the different antigenic type through the country. It is clear, however, that 3 different IBV types are coexisting in the north part of Egypt, an area that has a high poultry density.

Results indicated that one isolate code (16) was genetically related to the Mass type of IBV, while the other three isolates were not genetically related to the Mass type of IBV and seemed to be newly introduced pathogens in poultry population in Egypt. Variant strains of IBV were detected in vaccinated broiler flocks four or more weeks old, this can be explained by Massachusettes vaccine strains would have been replicating in high proportion of the birds during the first week. This may have competed variant field virus during the first few days after vaccination. This delay may be expected while the respiratory mucosae recovered from the replication of the Massachusettes vaccine. Possibly, some immune responses, including non-specific ones, to the Massachusettes type vaccine would impede replication of variant type (Cavanagh et al., 1999).

\section{References}

Ahmed, A.A.S. (1964): Infekiose Bronchitis des Huhnes in Aegypten. Berl. Munch. Tieraztl. Wschr., 77: 481-484.

Abdel-Moneim, A.S.; Madbouly, H.M.; Gelb, J.Jr. and Landman, S. (2002): Isolation and identification of Egypt/Beni-Suef/01 a novel infectious bronchitis-virus genotype. Vet. Med. J. Giza, 50(4): 1065-1078.

Abdel Moneim, A.S.; EL Kady, M.F.; Ladman , B.S. and Gelb, J.Jr. (2006): S1 sequence analysis of a nephropathogenic strain of avian infectious bronchitis virus in Egypt. Virology J., 78:

Adzher, A.; Shaw, K.; Britton, P. and Cavanagh, D. (1996): Universal digonucleotides for the detection of infectious bronchitits virus by the polymerase chain reaction. Avian Pathol., 25: 817-836.

Adzhar, A.; Gough, R.E.; Haydon, D.; Shaw, K.; Brition, P. and Cavanagh, D. (1997): Molecular analysis of the 793/B Seratype of infectious bronchitis virus in Great Britain. Avian Pathl., 26: 625-640.

Ahmed, H.N. (1954): Incidence and treatment of some infectious viral respiratory diseases of poultry in Egypt. Ph.D.Thesis, Fac. Vet. Med. Cairo University, Giza, Egypt.

Ahmed, M.E. (2002): Current status of infectious bronchitis disease in broilers at sharkia governorate. M.V.Sc. Thesis, Fac. Vet. Med. Zagazig. Univ., Egypt.

Ahmed, A.A.S.; Saber, M.S.; El-Sisi; M.A.; Reda, I.M. and Abbasi, K.H. (1968): Further studies on respiratory infections of poultry in Egypt. J. Vet. Sec. UAR., 5: 85-104.
Alexander, D.J. and Chettle, N.J. (1977): Procedures for the haemaggultination and haemagglutination - inhibition tests for avian infectious bronchitis virus. Avian Pathol., 6:9-17.

Amin, A. and Mostageer, M. (1977): A preliminary report on an avian infectious bronchitis virus strain associated with nephritis-nephrosis Syndrome in chickens. J. Egypt. Vet. Med. Assoc., 37 (2): 71-79.

Bastami, M.A.; Amer, M.M. and Hamouda, A.S. (1987): A viral nephritis induced by an isolate related to infectious bronchitis virus. 1. Isolation and identification of the isolate. Assiut. Vet. Med. J., 19 (37): 171-178.

Boursnell, M.E.; Brown, T.D.; Foulds, I.J.; Green, P.F.; Tomley, F.M. and Binns, M.M. (1987): Completion of the sequence of the genome of the coronovirus avian infectious bronchitis virus. J. Gen. Virol., 68: 57-77.

Cavanagh, D. (1989): Nucleic acid probes in the diagnosis and study of avian nononcogenic viral disease. In: Nononcogenic avian viruses. pp. 1-15.

Cavanagh, D. and Davis, P.J. (1988): Evolution of avian coronavirus IBV: sequence of the matrix glycoprotein gene and intergenic region of several serotypes. J. Gen. Virol., 69: 621-629.

Cavanagh, D. and Naqi, S.A. (1997): Infectious bronchitis. In B.W. Calnek, H.J. Barnes, C.W. Bearol, L.R. Mc Daugald, and Y.M. Saif (eds). Disease of Poultry $10^{\text {th }}$ Ed. Lawa University Press: Ames, IA, 511-526.

Cavanagh, D. and Naqi, S.A. (2003): Infectious bronchitis in Disease of poultry. B.W Calnek, H.J. Barnes, C.W. Beard, L.R. Mc Dougald and Y.M. Saif (Eds). Disease of Poultry, $11^{\text {th }}$ edn (pp101-119). Ames, IA, Iowa State University Press.

Cavanagh, D.; Davis, P.J. and Mockelt, A.P. (1988): Amino acids with hypervariable region 1 of avian coronavirus IBV (Massachusetts serotype) spike glycoprotein are associated with neutralization epitopes. Virus Res., 11, 141-150.

Cavanagh, D.; Davis, P.J.; Cook, J.K.; Li, D.; Kant, A. and Koch, G. (1992): Location of amino acid differences in the S1 spike glucoprotein subunite of closely related serotypes of infectious bronchitis. Avian Pathol., 21:33-43.

Cavanagh, D.; Mawditt, K.; Britton, P. and Naylor, C.J. (1999): Longitudinal studies of infectious bronchitis virus and avian pneumovirus in broilers using type-specific polymerase chain reaction. Avian Pathol., 28: 593-605.

Cook, J. K.; Orbell, S. J.; Woods, M. A. and Michael, B. (1999): Breadth of protection of the respiratory tract provided by different live-attenuated infectious bronchitis vaccines against challenge with infectious bronchitis viruses of heterologous serotypes. Avian Pathol., 28:477-485.

Cown, B.S. and Hitchner, S.B. (1975): Serotyping of avian infectious bronchitis virus by the virus-neutralization test. Avian Dis., 19: 583-595.

Davelaar, F.G.; Kouwenhoven, B. and Burger, A.G. (1984): Occurrence and significance of infectious bronchitis virus variant strains in egg and broiler production in the Netherlands. The Veterinary Quarterly, 6, 114-120.

De Wit, J.J. (2000): Detection of infectious bronchitis. Avian Pathol., 29: 71-93.

Eissa, Y.M.; Zaher, A. and Nafai, E. (1963): Studies on respiratory diseases: Isolation of infectious bronchitis virus. J. Arab. Vet. Med. Assoc., 23: 381-389.

El-Kady, M.F. (1989): Studies on the epidemiology and means of central of infectious bronchitis disease in chickens in Egypt. Ph. D. Thesis (Poultry Dis). Fac. Vet. Med., Cairo Univ., Giza, Egypt. 
Enjuanes, L.; Brian, D.; Cavanagh, D.; Holmes, K.; Lai, M.M.; Laude, H.; Masters, P.; Rottier, P.; Siddell, S.; Spaan, W.J.; Taguchi, F.and Talbot, P.(2000) Coronoviridae In: Virus taxonomy. Academic Press: New York, 835-849.

Gelb, J., Jr. (1989): Infectious bronchitis. In: purchase et al (Eds). A Laboratory Manual for the Isolation and Identification of Avian Pathogens. $3^{\text {rd }}$. Ed.AAAP, 124-127. Gelb, J., Jr.; Weisman, Y.; Ladman, B.S. and Meir, R. (2005): S1 gene characteristics and efficacy of vaccination against infectious bronchits virus field isolates from the United states and Israel (1996 to 2000). Avian Pathol., 34: 194-203.

Handberg, K.J.; Nielsen, O.L.; Pedersen, M.W. and Jorgensen, P.H. (1999): Detection and strain differentiation of infectious bronchitis virus in tracheal tissues from experimentally infected chickens by reverse transcription polymerase chain reaction. Comparison with an immunohistochemical technique. Avian Pathol., 28: 327335.

Ignjatovic, J.; Sapats, S.I. and Ashton, F.A. (1997): Long term study of Australian infectious bronchitis viruses indicates a major antigenic change in recently isolated strains. Avian Pathol., 25: 535-552.

Jackwood, M.W.; Kwon, H.M. and Hilt, D.A. (1992): Infectious bronchitis virus detection in allantoic fluid using the polymerase chain reaction and a DNA probe. Avian Diseases, 36: 403-409.

Jackwood, M.W.; Yousef, N.M.H. and Hilt, D.A. (1997): Further development and use of a molecular serotype identification test for infectious bronchitis virus. Avian Dis., 41: 105-110.

Jia, W.; Karaca, K.; Parrish, C.R. and Naqi, S.A. (1995): A novel variant of infectious bronchitis virus resulting from recombination among the different strains. Arch. Virol., 140: 259-271.

Karaca, K.; Naqi, S. and Gelb, J.Jr. (1992): Production and characterization of monoclonal antibodies to three infectious bronchitis virus serotypes. Avian Dis., 36: 903915.

Keeler, C.L.; Reed, K.L.; Nix, W.A. and Gelb, J.Jr. (1998): Serotype identification of avian infectious bronchitis virus by RT-PCR of the peplomer (S1) gene. Avian Dis., 42: 275-284.

Kingham, B.F.; K eeler, C.L.;Nix, W.A.; Ladman, B.S. and Gelb, J.Jr. (2000): Identification of avian infectious bronchitis virus by direct automated cycle sequencing of the S1 gene. Avian Dis., 44:325-335.

Koch, G.; Hartog, L.; Kant, A. and Van Roozelaar, D.J. (1990): Antigenic domains on the peplomer protein of avian infectious bronchitis virus: Correlation with biological functions. J. Gen. Virol., 71: 1929-1935.

Kusters, J.G.; Niesters, G.M.; Bleumink-Pluym, N.M.; Davelaar, F.G.; Herzinek, M.C. and Van der Zeijst, B.A. (1987): Molecular epidemiology of infectious bronchitis virus in the Netherlands. J. Gen. Virol., 68: 343-352.

Lai, M.M. and Cavanagh, D. (1997): The molecular biology of coronoviruses. Adv. Virus Res., 48: 1-100.

Lebdah, M.A.; Eid, Amal, A.M. and El-Shafey, A.M. (2004): Infectious bronchitis virus infection among meattype chickens in sharkia province (Egypt). Proc. IV. Int. Symp. On avian Corona-and pneumovirus infections.
Rauischholzhausen, Germany, 20-23 June, 2004. pp. 75-86. Liu, H.J.; Lee, L.H.; Shih, W.L.; Lin, M.Y. and Liao, M.H. (2003): Detection of infectious bronchitis virus by multiplex polymerase chain reaction and sequence analysis. J. Virol. Meth., 109: 31-37.

Madbouly, H.M.; Abdel-Moneim, A.S.; Gelb, J.Jr.; and Landman, B.S. (2002): Molecular characterization of three Egyptian isolates of infectious bronchitis virus. Vet. Med. J. Giza, 50 (4): 1053-1064.

Mahmoud, A.R. (1993): Viruses associated with Coryza infection in chickens. M.V.Sc. Thesis (Poultry Dis). Fac. Vet. Med. Zag. Univ. Egypt.

Meulemans, G.; Boschmans, M.; Decaesstecker, M.; Van den Berg, T.P.; Denis, P. and Cavanagh, D. (2001): Epidemiology of infectious bronchitis virus in Belgian broilers: a retrospective study, 1986 to 1995. Avian Pathol., 30: 411-421.

Mousa, S.A.; Ibrahim, Nahed, G.; Shehata, M. and Soliman, A. (1988): Epidemiological studies on nephritisnephrosis syndrome. Proc. $3^{\text {rd }}$. Cong. Fac. Vet. Med. Assiut. Univ., Nov., 20-22, pp. 335-341.

Niesters, H.G.; Lenstra, J.A.; Spaan, W.J.; Zijderveld, A.J.; Bleumink-Pluym, N.M.; Hong, F.; Van Scharrenburg, G.J.; Horzinek, M.C.; Van de Zeijst, B.A. (1986): The peplomer protein sequence of the M41 strain of coronavirus-IBV and its comparison with Beaudette strains. Virus Res., 5:2825-2831.

Sediek, M.M. (2005): Studies on infectious bronchitis in chickens. M.V.Sc, thesis, poultry Dis, Fac. Vet. Med. Alex Univ. Egypt.

Seo, S.H. and Collisson, E.W. (1997): Specific cytotoxic T lymphocytes are involved in vivo clearance of infectious bronchitis virus. J. Virol., 71: 5173-5177.

Sheble, Atiat.; Sabry, M.Z.; Davelaar, F.G.; Burger, A.R.; Khafagy, A.K.; Moustafa, M.M.; Fawzia, M. and Henna, M. (1986): Present status of infectious bronchitis in Egypt. J. Egypt. Vet. Med. Assoc., 64(4): 393-411.

Song, C.S.; Lee, Y.L.; Kim, J.H.; Sung, H.W.; Lee, C.W.; Izumiya, Y.; Miyazawa, T.; Jang, H.K. and Mikami, T. (1998): Epidemiological classification of infectious bronchitis virus isolated in Korea between 1986 and 1997. Avian Pathol., 27: 409-416.

Sultan, H.A.; Tantawi, Lila, A.; Youseif, Aml, I. and

Ahmed, A.A.S. (2004): Urolethiasis in white commercial egg laying chickens associated with an ifnectious bronchitis virus. Proc. $6^{\text {th }}$. Sci. Conf. Egypt. Vet. Poult. Assoc., pp: 155-169.

Wang, C.H. and Tsai, C.T. (1996): Genetic grouping for

the isolates of avian infectious bronchtis viruses in Taiwan. Arch. Virol., 141: 1677-1688.

Wang, L.; Junker, D. and Collission, E.W. (1993): Evidence of natural recombination within of S1 gene of infectious bronchitis virus. Virology, 192: 710-716.

Wang, L.; Junker, D.; Hock, L.; Ebiary, E. and Collison, E.W. (1994): Evolutionary implications of genetic variations in the S1 gene of infectious bronchitis virus. Virus Res., 34: 327-338.

Williams, A.K.; Wang, L.; Sneed, L.W. and Collisson, E.W. (1992): Comparative analysis of the nucleocapsid genes of several strains of infectious bronchitis virus and other coronaviruses. Virus Res., 25: 213-222. 


\section{مدى انتثار مرض الإلتهاب الثعبى المعدى فى بعض قطعان الدجاج \\ Y. التوصيف الجزيئى لفيروسات الإلتهاب الثعبى المعدى المعزولة من إصابات حقلية}

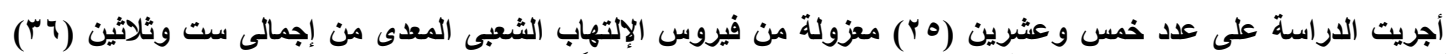

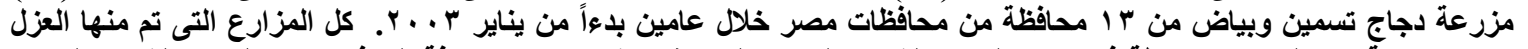

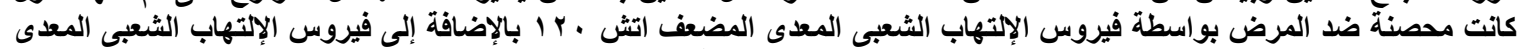

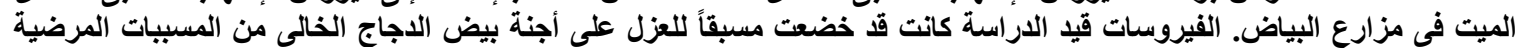

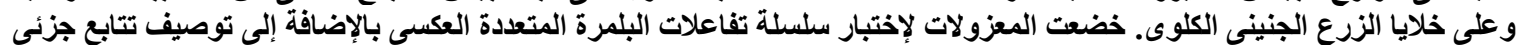

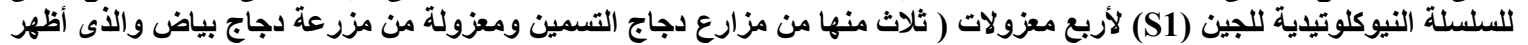

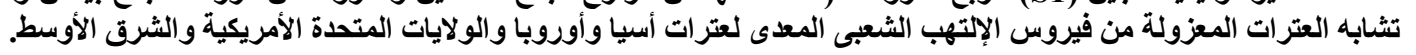

